\title{
Calvin the preacher: His explanation of the doctrine of predestination in the sermon of 1551 and in the Institutes of 1559.
}

\author{
W H Neuser \\ Ostbevern, Germany \\ Secretary: International Congress on Calvin Research
}

\begin{abstract}
In this study, Calvin's famous sermon on eternal election of 1551 is discussed and compared to his treatment of the doctrine in his Institutes, 1559. This is a necessary study, never undertaken before, of the correlation between Calvin's pastoral treatment of the Biblical doctrine of predestination and his more didactic-apologetic approach in the Institutes. Here the main argument in the sermon is summarised and, at every point, the corresponding passage in the Institutes is also discussed and the difference in approach and argument evaluated. In this way a more complete knowledge of Calvin's understanding of this doctrine is gained. To assist the reader, the text of the sermon of 1551 is also published. The final conclusion is that the sermon is a valuable addition to the Institutes. Without.it, Calvin's pastoral treatment of the doctrine is ignored when evaluating his exposition on eternal election.
\end{abstract}

\section{INTRODUCTION}

On 16 October 1551, Jerome Bolsec voiced his opposition to the doctrine of predestination in The Congrégation; on 23 December the Little Council of Geneva ordered his banishment. On 18 December, however, Calvin had preached a sermon on the predestination of God. What gave rise to this sermon?

In November, as well as on the day after Bolsec's banishment, several Genevans were summoned before the Consistoire for having openly sympathized with Bolsec's doctrine $^{1}$. For this reason, the Compagnie des Pasteurs decided on 11 December 'that as the communion was getting near, it would be well to remedy the trouble which had been caused by Maitre Jerome [Bolsec], so that steps could be taken to ensure that the sacrament was not polluted by any who might have been infected with his error. In order to do this it was resolved that on the following Friday the matter should be placed before the Congregation, with Calvin explaining the situation' et cetera ${ }^{2}$. 
This is not the only extant sermon of Calvin on predestination ${ }^{3}$ but it is the only one that was preached on a Friday in the Congrégation ${ }^{4}$ on which all the preachers expressed their views. In 1560 , together with a reprint of his Traité de la predestination eternelle against Bolsec (1552), Calvin's Treze sermons de l'election gratuite de Dieu was published. The latter consisted of Calvin's sermons on Genesis 25, 11-27, 36 which were preached on 8-27 July of the same year ${ }^{5}$. Apart from these, the second to fifth sermons on Ephesians (Eph 1, 4-14) should also be considered. These formed part of a series of sermons preached during the afternoon services from 15 May 1558 onwards 6 . The sermon of 18 December 1551 , which is examined here, is of special significance because of the circumstances which brought it about. It was only printed in $1562^{7}$.

What did Calvin preach on this doctrine? The sermon should be compared with the Institutes III, 21-24. It is not proposed to take the contemporary publication, De aeterna praedestinatione (1552) as a comparison, as this was a polemical treatise against Pighius, Georgius Siculus and Bolsec. It was of a purely apologetic character.

As the sermon is extraordinarily comprehensive ${ }^{8}$, even without the views of the other pastors, it must be assumed that it was expanded afterwards. Intrinsic arguments (see later) lead to the conclusion that the justification of the 6th objection, as well as objections 9-11, were final additions. This possibility, however, should not be allowed to play any role in the following comparison.

The French text is published in CO 8, 89-119. Ph C Holtrup produced a good English translation ${ }^{9}$, which is used for the English citations in this article. There is also a good Dutch translation by D v Dijk, in Stemmen uit Genève. Preken, artikelen, brieven enz. van Johannes Calvijn, Deel III, 7-61. De Gereformeerde Bibliotheek te Goudriaan 1971. The Dutch text will be followed here (cf the appendix). The reprint in the appendix is completed by biblical references and headings of the different sections. The quotations refer to the pages and paragraphs of the Dutch text.

\section{SERMON AND INSTITUTES}

From the base they differ, because the sermon is determined by the thesis of Bolsec: Predestination depends on faith. Calvin repeatedly stated the opposite view: Predestination precedes faith $(81,4 ; 83,2 ; 85,2$ as well as 88,1$)$ or also: Faith depends on a higher and hidden source $(80,1 ; 81,2)$. This antithesis is reiterated in the first part, in which the biblical texts on predestination are discussed.

The Institutes, on the other hand, is determined by opposition to the opposing thesis on the praescientia Dei: God elects those of whom he knows in advance that they will believe. Also, Calvin's repudiation of this thesis is found in the Institutes at such places where he expounds the related Bible passages (III, 22, 1-4, 8-9, 23, 6-7). 
The fact is, that the repudiation of Bolsec in the sermon and the rejection of the Sorbonnists (97,2; papist theologians 88,1 ) in the Institutes are virtually identical. The precedence of faith in relation to election (Bolsec) and God's consideration of prospective faith in His electoral decree (Catholic opposition) are merely two different aspects of the same matter. The basis of the first statement is the faith of man, the basis of the second is God's act before all time. Of course, Calvin also discusses the thesis on the foreknowledge of God in the sermon $(82,2 ; 88,1 ; 97,2)$. But the thrust of the sermon differs from that of the Institutes. In the Institutes, Calvin very seldom regards the faith of the elect (III, 22, 10; 24, 3-7). In the exposition of the praescientia Dei, the act of God enjoys precedence and as a consequence the discussion is of a doctrinal, theoretical nature. Putting faith in the foreground, on the other hand, the congregation was addressed in a very direct and practical way. The Institutes is predominantly based on disputed tenets, whereas the sermon is directed immediately to the faith of the congregation. The consequences of this statement must be looked at.

\section{BIBLICAL PASSAGES: PART 1}

In the sermon Calvin expounds four biblical passages, or rather, four groups of passages: Ephesians 1, 4ff, Romans 8, 28-30, John 6, 44f, 10, 28f, (as well as other passages which prove the doctrine of particular redemption) and Romans 9, 6-15.

Institutes III, 22 is also dedicated to biblical proof. There he discusses Ephesians 1, 4ff, Romans 9, 6-15, John 5, 37ff, and 44f, 10, 28, 17, 9ff. Apart from Romans 8, 28-30, the passages are the same. It is amazing that this important passage is not interpreted in Institutes III, 21-24, because in this passage Calvin uses the concept of God's foreseeing. Why does Calvin say nothing about biblical passage from which his opponents extracted their main arguments? There is no plausible explanation for the omission of this passage. But how does he interpret this passage in the sermon?

\subsection{Romans 8, 28-30}

In the sermon, Romans $8,28 \mathrm{~b}$ is discussed at first: 'to those who are called according to God's purpose'. God is the acting person if they are called. Human action, namely 'those who love him', is subordinated to the calling of God and his design is his electoral decree (Eph 1, 5 \& 9). In Institutes III, 24, 1 Calvin also touches, in passing, on the 'efficacious and powerful calling' as an expression of God's election. This is the only place in the Institutes where Romans 8, 28 is mentioned.

In the sermon, therefore, Calvin confronts those opponents who relate the foreseeing of God to the following action of man 'that they would believe in him and would make good use of his graces' $(82,2)$. Calvin rejects this interpretation by referring to 
Romans 11, 2: 'God did not reprove his people whom he had foreknown'. Was the whole people thus 'worthy of such grace'? No, only a 'remnant' was saved ( $R m$ 9, 27) $(82,2)$. In this way Calvin explains his concept of the 'foreknowledge' of God in Romans 8, 29.

Finally he cites Acts 2, 23: Christ is referred to in preaching 'according to the foreknowledge of God'. The pronouncement that God's predestination is grace is often repeated in the sermon. Already in the interpretation of Romans 8, 28 it said in the beginning: 'God turns all things to the good of those who love him'. This love of God emanates from God, not man: 'that immutable counsel in God ... finds in his own. goodness the cause for doing this or that' $(81,4)$. The electoral decree of God is also the 'goodness' of God. This very direct, pastoral interpretation of 'God's counsel' is repeated several times in this passage.

\subsection{Ephesians 1, 4-9}

The interpretation of this central biblical pronouncement on predestination is in full agreement with the exposition in Institution III, 22, 1-3. In the sermon, Calvin calls his theme: 'We observe ... that the holy apostle Paul constructs between these two opposing things: the work of man, on the one side, and the purpose of God, on the other' $(80,3)$. He then puts forward the basic statement of the doctrine on predestination: God finds in man only 'misery and poverty' $(81,1)$. Thus God is not 'unjust' when he elects only some people $(81,1)$. With that Calvin counters the objection that the doctrine of particular salvation would be unjust. It should be noted that once again the decision of God is proclaimed to be God's act of grace to us: Paul understands the Counsel of God as 'to do us any good' $(80,3)$.

The sentence 'elected us in Jesus Christ' (Eph 1,4) is interpreted in a soteriological and pastoral sense: God does not regard us as we are, but 'in his son (Eph 1,6) and therefore he loves us' $(81,2)$. Again Calvin denotes the electoral decree as grace: 'God illumines those whom he has chosen by his gracious goodness before the creation of the world' $(81,5)$.

This pastoral interpretation is absent from the Institutes III, 22, 1-3. The explanation of the words 'in Christ' being God's turning to us 'in his beloved' (Son) is also absent. Here, the 'holy and blameless before him' (Eph 1,4) is dominant in God's act of election. Of course, Calvin teaches that the sanctification of believers is dependent on God's eternal decree. Furthermore, the refutation of a foreknowledge of faith by God, as well as the emphasis (as in the sermon) on the precedence of election before faith, are dominant (OS IV, 381, 12). 
As a deviation from the sermon, Calvin stresses in the Institutes the words 'according to the purpose of his will' (secundum benevolentiam voluntatis suae) (Eph 1, 5 \& 9) (OS IV, 381, 16.18). The divine benevolence is God's discretion rather than his love. 'Now if a higher cause be sought, Paul answers that God has predestined it so, and that this is "according to the good pleasure of his will". (Inst III, 22, 2; OS IV, 381, 34f). God's pleasure is not his love as in Luke 2, 14, but mainly his discretion, his choice, his will (see Inst III, 21, 1.5, 22, 7, 23, 4. 24, 17; OS IV, 369, 29; 375, $32 ; 388,13 ; 398,21 ; 431,23)^{10}$. In the sermon, on the other hand, Calvin does not expound 'God's purpose', but the 'beloved' Son. There his purpose is: 'we see how we should know fully the grace of God: when we are persuaded and convinced that he has not only given us faith, but has also given it to us because he chose us by his will "before the creation of the world"' $(80,2)$. Calvin wants to put human faith and divine grace in close proximity to the congregation. In the Institutes, his concern is mainly systematic: God's working alone and man's impotence, or rather salvation, reside only in the God-given faith.

\subsection{John $6,44,10,28$ and similar passages}

These biblical passages state the fact that God works alone. In contrast to them, a seeming universal salvation is referred to (Is 54,13 ; Ezk 37, 24; 36, 27; 37, 26; Jr 16, 59ff; $17,13 \mathrm{ff})$. In the sermon Calvin calls these passages 'universal promise' $(84,2)$. But, since most people have 'hearts of stone (Ezk 36, 26), we have to 'realize that this promise is particular $(84,3)$. 'We must therefore conclude that this does not come from our own power - or our dignity and merit - but only from the pure grace of God' $(84,3)$.

A summary at the end of the passage allows for a comparison with the corresponding passage in the Institutes. In the sermon the three points are: First, 'election precedes faith'. And the explanation: 'The Father gives to his Son what is already his own $(85,3)$. Secondly, 'Our salvation is certain .... Because it rests in the hand of God ... he has put it in the hand of our Lord Jesus' $(85,4)$. Thirdly, 'Faith is the means by which he (God) calls us .... And we begin to "hear his voice"' $(86,1)$.

It is noticeable that the way is described from the electoral decree of God, which is 'concealed', $(86,1)$ via Christ, in whom our election is certain, to the hearing during the preaching and finally to faith.

The same is found in Institutes III, 22, 7 and 10, though if not systematically arranged. (1) John 6, 37 and 39: 'Note that the Father's gift is the beginning of our reception into the security and protection of Christ' $(22,7)$. (2) 'Although the voice of 
the gospel addresses all in general, yet the gift of faith is rare. Isaiah sets forth the cause: that "the arm of the Lord has" not "been revealed to all"' $(22,10)$. (3) 'And indeed, faith is fitly joined to election, provided it takes second place' (Jn 6, 39f; III, 22,10 ). (4) 'Now because the testimonies that $I$ have quoted express perseverance, they at the same time attest the unvarying constancy of election' $(22,10)$. The way from the decree of God, via Christ, to the proclamation of the gospel and finally to faith, is indeed there, but only in the sentences which we have selected from many passages.

\subsection{Romans 9, 6-20}

In the sermon, Calvin immediately passes from the 'children of promise' $(\operatorname{Rm} 9,8)$ to Christ, 'king of the whole world' $(86,2)$.

Then he makes an interesting remark: 'So then, that is how all the earth is called to salvation in the name of our Lord Jesus Christ. But this is not to say that all are heirs of the promise in truth. And why? Saint Paul could certainly have stated that not all believe - but he did not do so because of an oversight. He omitted it, however, to say that God elects those whom he desires' $(86,3)$. Since Calvin wants to deal with human faith in his dispute with Bolsec, he has to establish the fact that the word faith does not appear in Romans 9, 1-29. Only in Romans 9, 30ff does he deal with justification by works and through faith. Calvin explains it thus: Paul could have said that not all of Israel believe; that he did not do so was no 'oversight'; he wanted to emphasize the will of God $(\mathrm{Rm} 9,18)(86,3)$. In the Institutes Calvin does not comment on the peculiarity of this passage. He merely remarks that Paul does not deal with the evil of Esau, which would have been the most certain proof of God's justice (Inst III, 21, 11).

The following statement of the sermon is also lacking in the Institutes: Paul had a particular knowledge on predestination, because he had been taken up into the third heaven ( 2 Cor $12,2 \mathrm{ff})$. A rather forced exegesis!

For the rest, Calvin presents the normal exegesis of Romans 9, 6-20. He summarizes: 'God has elected us not only before we knew him, but before we were born, and before the world was created. He has elected us by his free goodness - and he did not look for any other cause' (etc) $(92,2)$. Again, the pastoral consolation of God's goodness is connected to the essential doctrinal statement.

The explanation of Romans 9 is found in Institutes III, 22, 4-6. Apart from the differences mentioned above, the content corresponds with that of the sermon. 


\section{OBJECTIONS TO THE DOCTRINE OF PREDESTINATION: PART II}

In the sermon Calvin cites eleven objections. So too Institutes III, 23 deals with objections; there objections numbers 1-8 and 11 recur. More objections are found in Institutes III, 24 (objections $9 \& 10$ ). The refutations are only partly identical. Precisely for this reason they should be compared. The similarity or rather the dissimilarity in thought is very informative.

The form of the objections differs in the two documents. In the sermon almost all objections are put as questions, with the result that Calvin's style is very lively. Often the objections are repeated in a different way. The style in the Institutes is rather dull.

1st Objection: 'Behold, I am afraid of making God unjust if I profess that he has elected those whom he has pleased $[R m 9,18 a]$ ' $(90,3)$. Or with a view to Romans 9 , 18b: 'Oh, I fear that I would charge God with cruelty if I contended that he does not elect every human being' $(90,3)$. It is plainly the objection of a simple member of the congregation, who, under influence of Bolsec, does not wish to connect God with the particularity of redemption. Calvin answers somewhat harshly: 'My friend you only show in this way the hidden pride in your heart, and the fact that you have still not acknowledged the hypocrisy that is in you' $(90,3)$. Why does Calvin accuse the questioner of pride and hypocrisy? The questioner is referring to Romans 9, 18; he does not want this plain word on God's elective and/or condemning act to be true. That is the reason for Calvin's harsh rebuttal.

The next passage cites an argument a minore ad maiorem. If in Romans 14, 10-13 Paul forbids any judgment on the life of one's brother, how much more so in case of God's actions? 'If Saint Paul does not want us to be audacious in so judging each other, then let us be careful, I pray, when we begin to elevate ourselves against God' $(91,2)$.

Calvin develops the thought about judgment on God and specifically defines the objection that God could be unjust: 'I fear God would be unjust if he act in this manner' $(91,2)$. Calvin concludes the objection: So God's will must be accommodated to our comprehension or his motives must be clear to us. Again Calvin answers sharply: 'You are afraid that God would be unjust if he did not subject himself to you! — or if you did not control him, ... as if he were inferior to you! But what kind of arrogance is that'? $(91,2)$.

Calvin again phrases the objection in another way: 'I do not know if God is just. Let him show me how and why' $(91,2)$. His answer is pastoral: we should live humbly until the day when the 'book will be open' (Dn 7, 10); then we shall know why Jacob was elected but Esau rejected $(91,3)$. This whole train of thought is missing in the Institutes. 
But then he gives - as Institutes III, 23, 1.4 and 5 - his standard information, that Paul would be saying in Romans 9, 20: 'Oh man, who are you to elevate yourself against God?' $(92,1)$. In the sermon Calvin gives a vivid explanation of this word of Paul: Let us pretend that God had submitted himself to our judgment and that he is standing in front of a judge, defending himself. The judge would ask: 'Do you have anything to say about this? (and God would answer:) Here is why I did it'. If God should answer in this way, would we still be able to imagine the glory and majesty of God? We would not be able to suffer his majesty but would cast ourselves in an abyss, should we maintain such audacity $(92,1)$. Calvin gives the congregation a very vivid impression of his thought.

Once again Calvin reverts to the objection that God is unjust. This objection moved him most of all and he gave most attention to it: We should know our own capacity for understanding. God's will is hidden to us. But we can be sure that he has just cause for his actions. Some day we shall know 'face tot face' what is now hidden from us (I Cor 13, 12) $(92,2 ; 98,2)$.

In the Institutes, the defence and the explanation of the justice of God against 'moderate' people is lacking, as well as the firm but pastoral refutation of their objection. In Institutes III, 23, 1.4 and 5 he deals very harshly and relentlessly with his adversaries (See Objection 4).

2nd Objection: 'One could get along very well without this doctrine and preach faith and repentance without saying that some are elect of God' (92,3). Again this objection seems to come from a simple member of the congregation. In the sermon Calvin admonishes that the inclination to be modest should be overemphasized and that one should not withdraw oneself from the Word of God. He does not present any Bible passage, but merely refers to what has been said previously. The sum of it: Predestinations precedes faith. In the Institutes the danger of keeping quiet on predestination appears in Institutes III, 21, 3; the proposal for limiting preaching to faith and repentance appears in Institution III, 22, 10.

Now Calvin deals with the objections of the blasphemers $(93,2)$.

3rd Objection: 'If God has elected those whom he pleases [Rm 9, 18], we need not believe that we should strive to live a holy life, since God's election includes everything' $(93,2)$. Or 'If God has elected us, men must loosen the reins and let themselves go free' $(93,3)$. Or: 'Indeed, if we are elect, it follows that we certainly can do evil, since we cannot perish' $(93,3)$. Calvin calls the last two statements 'stupid'. He calls 
to mind Ephesians 1, 4 'elected that we should be holy' $(93,2)$, but does not dwell on this objection. He uses a metaphor: Anyone who separates election from one's way of life argues like someone who separates the light from the sun and says: 'It is enough to have a sun, we do not need the light' $(93,2)$. In Institutes III, 23, 12 this is the 'third objection'. With regard to content they correspond.

4th Objection: 'Alas, if God elects those whom he pleases and rejects the others, he would be unjust' $(94,1)$. Calvin calls this objection 'the principal blasphemy' $(94,1)$ : He calls to mind that indeed the first protest was 'afraid' about God's justice. The modest proponents of this view sought to honour God, but they do not know how God should be honoured.

Calvin's judgment becomes very severe. Even the modest people are already in the grip of Satan; but those who are now talking, are fully in his power.

In the sermon Calvin again uses a metaphor: 'If I pull a stone on my head, where will it come down? When we throw stones at each other, we may manage not to be struck and the blows may not touch us' $(94,2)$. Calvin means one may avoid stones that are thrown. 'But with whom are we contending when we speak against God? If we want to fire the harquebus, or throw javelins, or shoot arrows and other missiles over our heads, will they all fall back on us and crush us?' $(94,2)$. Thus, to speak against God means the same as to hurl a lot of arrows, javelins and other missiles into the air; will certainly fall on our heads and crush us. The same will happen if we turn against the majesty of God. An impressive metaphor which says a lot more than doctrinal statements on the difference between God and man! Calvin forgoes any Bible passages when dealing with this objection.

In the Institutes the first objection deals with God's justice (III, 23, 3-5). There Calvin explains God's choice, his majesty and his greatness to the full, making use of Bible passages. Objectively the metaphor on thrown weapons in the sermon ${ }^{11}$ and the refutation from the Bible in the Institutes are identical, although the manner of speech differs.

5th Objection: Some find it strange that there is no simple answer to the question of God's justice. They say: 'I want someone to explain things to me more clearly, so that I can understand why this sort of thing is done $(94,3)$. Calvin deals with this very briefly: 'My friend you will have to look for another school $(94,3)$. Institutes III, 21 , 3: Holy Scripture is the school of the Holy Spirit. When Calvin talks about 'another school' in the sermon, he hints that 'school' is the common denominator for the 
scholastic systems of the Thomists, the Scotists, and the Occamists. In contrast to them, the Holy Spirit sets a limit to our questioning.

In the explanation on what is to be learnt in the school of the Holy Spirit, Calvin obviously refers back to Institutes III, 22, 1 where those who quarrel with God are refuted. His purpose is to show how inappropriate their dealings are. Since the examples first appeared in the Institutes of 1559 , and are dogmatically complex, one may assume that they were a later addition to the sermon.

The first comparison with wild animals only becomes comprehensible from the text of the Institutes: 'Let them answer why they are men rather than oxen or asses. Although it was in God's power to make them dogs, he formed them to his own image. Will they allow brute beasts to argue with God about their condition as if the distinction were unjust'12. He points to the sublimity of the Creator in relation to his creatures. If the scope is clear, the passage in the sermon of Calvin is much livelier $(95,2)$.

The second example puts forward the sublimity of the divine nature of Christ in relation to human nature. The passage in Institutes III, 22, 1 reads: 'If they shift the argument to individual persons where they find the inequality more objectionable, they ought at least so to tremble at the example of Christ as not to prate so irresponsibly about this lofty mystery. He is conceived a mortal man of the seed of David. By what virtues will they say that he deserved in the womb itself to be made head of the angels, only begotten Son of God, image and glory of the Father, light, righteousness, and salvation of the world ${ }^{13}$ '. In the sermon, the text is also livelier, but with the same content $(95,4)$.

Between the two comparisons, a citation from Augustine has been interpolated (95, 3), which depicts Christ as the mirror of election. Since he is the head of the church, we, the members, should look upon him. In Institutes III, 22, 1, an election by Christ is mentioned ${ }^{14}$.

6th Objection: 'We must find it strange how God rejects the reprobates, since they are his creatures' $(96,1)$. Again Calvin's reply is not informative but short and sharp. He points out that in fact all men were rejected because of their sins, and then he reminds us of the workers in the vineyard. The owner of the vineyard calls all of them, but he pays them as he sees fit. 'Is it not my right to do what seems good to me with what is mine? If I am good and generous, will your eye be malicious? (Mt 20:15).

Institutes III, 23, 4 deals with the same objection, but without the parable. The motive can be surmised: the owner indeed pays according to his choice, but he pays all of them, he doesn't omit anyone. 
7th Objection - this combines a range of protests: (1) 'Well, but when God created Adam, did he not foresee what was going to happen? (2) Did he not dispose of this matter according to his will?' (96,3-97,3). Calvin answers the last question by pointing out that creation was good and that Adam's fall cannot be blamed on God. (3) 'Yes, but if God did not decree it, it would not have so happened'. And (4) 'How did God permit it to take place? Could he not have remedied this situation?' Again Calvin points to God, who is the Judge, and to the fact that his councel is hidden to us. Our answers open up an abyss which endagers us. 'If we see an abyss before us, who will cast himself into it?' $(96,3)$ God acts according to his choice $(\operatorname{Rm} 9,19 f)$.

Only at the end does Calvin address the argument of the 'Sorbonnists' who reasoned that God had foresaw the wrong decision of man, and elected or rejected according to that decision. He points to God's choice, namely to do what he wants (Rm $9,18)(97,3)$.

In the Institutes these questions belong to the second body of objections (III, 23, 69). God's foreseeing $(23,6)$, Adam's fall $(23,7)$ God's permitting will $(23,8)$, God's creation was 'very good', Adam fell through his own evil, God's inconceivable predestination $(23,8)$. The sermon and the Institutes concur objectively. The sermon, however, collects these questions and refutes them in a very concise manner. It is clear, then, that all these questions emanate from an alleged defence of God and that they ostensibly want to make God's actions appear plausible. Calvin can only answer that God had indeed arranged everything, but his decision is hidden from us. In his textbook, Calvin deals with all objections more comprehensively and exhaustively, but it is less clearly that all the objections emanate from the same source and that they are countered with the same negative answers.

8th Objection: 'Well then, I cannot be content unless someone gives me a clear reason' $(97,3)$. Calvin gives a remarkable answer. He points to the preceding arguments and to the 'feeling in our hearts' and to the 'evidence in our conscience' $(97,3)$. What is meant by the latter? It is not an interior testimonial of the Holy Spirit as in the case of the authority of Scriptures. Rather, a simple interior knowledge is referred to: that we are guilty before God and that we stand condemned as a result of our sins.

It is the soteriological evidence that election is unmerited. Those who question lack self-understanding. Calvin says: 'If we want to profit in the doctrine of the gospel, we must know what is from God and what is from us' $(98,1)$. The reprobate are simply not elected by God. So God is indeed just. Again Calvin refers to the eschatological judgment in which God's justice will be revealed, 'when we see him face to face' $(1$ Cor 13,12$)(98,2)$. 
In the Institutes these considerations are found in Institutes III, 23, 3 (1st Objection). Only the reference to the eschatological judgment, where all questions will be answered, is lacking. Apart from that, the sermon and the Institutes are in agreement. Nevertheless, the sermon contains a much stronger appeal to the interior insight into the basic human situation before God.

\section{Calvin's summary}

In the sermon, Calvin gives now a summary of what has been said thus far. We do not find the pastoral language in the first person plural and the simple christocentric train of thought in the Institutes, not even in the splendid passage III, 24, 5. The summary reads thus: 'Now then, let us sum up all that we have said regarding God's election. We should notice that we do not glorify God as we should - and do not recognize his grace as he displays it to us - unless we realize that he has elected us, and has even removed us from the universal condemnation that has come on the entire race of Adam, in order to lead us to our Lord Jesus Christ. It is he alone who has ransomed us. But still, let us consider the reprobate, and learn to look at ourselves in their persons. We shall then say: 'It could be so with us, if God had not employed his fatherly goodness to separate us from them. We cannot distinguish ourselves by nature - but God has rendered us more excellent (cf Ps 8, 6f). As I have stated, the faithful man will never glorify God appropriately until he has come to that point' $(98,3)$. The sympathy, indeed the involvement with the reprobate, is striking; this is not found in the Institutes.

This summary probably concluded the sermon preached to the congregation. The following three objections seem to have been added by Calvin at a later date. This can be deducted from the introductory sentence: 'I shall now lay out in brief the whole case that can be alleged at this juncture' et cetera $(98,3)$. Calvin thus returns to Bolsec and answers a few final objections. The style with its introductory questions is maintained.

9th Objection: Bolsec says: 'Look, God wants all men to be saved - and come to the knowledge of the truth' (1 Tm 2:4) $(99,1)$. This would be Bolsec's main argument. Actually, this objection had already been dealt with in the first enquiry, although without reference to 1 Timothy 2,4 . The meaning of the Bible passage is now expanded. Somewhat revised, the objection reads: 'Look, is not the gospel preached throughout the world?' $(100,2)$. Calvin had already previously pointed out that God had not sent any preachers to the Turks $(99,1)$. 
To the first objection, Calvin gives the answer, namely that Paul refers to corporate bodies, not individuals. To 2 Timothy 2, 25 he opposes Ezekiel 18, 32. Calvin's argument corresponds with that in Institutes III, 24, 16.

To the second question Calvin retorts: But 'Who has believed our preaching?' (Is $53,1)$. It is simply a fact that not all the people to whom the gospel is preached believe. In Institutes III, 24, 17 the answer is put in a less popular way, but the answer remains the same.

10th Objection: 'How do I know if I am saved or damned?' $(101,1)$. The assurance of salvation is questioned. Calvin's answer is simple. Through faith in Jesus Christ, we are assured of salvation. This assurance is given to us by the gospel. In Institutes III, 24, 5 the reference to Christ and the preaching of the gospel is at least as impressive as in this answer.

11th Objection: This objection is concerned with the question regarding the inevitability of all that happens $(101,4)$. It is not by chance that a formulated question is lacking, because it is a philosophical question. It is all the more surprising to find the related question in Institutes III, 23, 6: 'Why should God impute those things to men as sin, the necessity of which he has imposed by his predestination?' The train of thought in both documents is virtually the same. It is concerned with the foresight of God.

Calvin's final remark that he had not dealt with the matter in full $(102,3)$, can, in relation to the Institutes, only mean that some of the themes found in Institutes III, 24 are lacking, for example perseverance $(24,7)$, Judas $(24,9)$, seed of election $(24,10)$, induration $(24,13-14)$. All of this indicates that Calvin added objections 9 to 11 at a later date. But then, he would not have preached on the assurance of election in the sermon of 1551. As has been shown, however, his theme at that stage was a limited one, namely 'predestination preceedes faith'.

\section{RESULT: PART III}

* Sermon and textbook have different functions for Calvin. Calvin expounds a theme in a sermon on the predestination of God, which may be designated as a dogmatic sermon. The sermon and the Institutes are therefore closely related. However, the comparison of texts provided above bears out the fact that Calvin is not only livelier but also more pastorally oriented in the sermon. Even if there is a clear fundamental consensus, the theological presentation of the predestination of God will be different in the sermon. 
* The Institutes is, generally speaking, a textbook. It would be wrong to call it a dogmatic manual. One would miss the point that biblical exegesis and dogmatics were divided only in about $1600 \mathrm{AD}$. It was only at the turn of the 16 th to the 17th century that the Protestant universities and centres of higher education began to lecture in dogmatics ${ }^{15}$. Until then, there were merely lectures on the different books of the Bible. Also the Institutes and other comparable works were designed only to summarize the exposition of the Bible and to defend it against opposing opinions. The apologetic task, however, demanded a certain systematic cohesion. This makes the Institutes something very like a dogmatics. As a textbook on biblical exegesis, the Institutes expounds essentially the same theme as the sermon. Therefore it is all the more remarkable that other theological emphases occur in the sermon.

* The apologetic task, which of necessity has to refer to history and philosophy, and which demands rational clarity and cohesion, differentiates the Institutes from the sermon. Although Calvin has an apologetic inclination in this sermon, his pastoral inclination predominates. Of necessity this aspect is not dealt with sufficiently in the Institutes. What one must ask is how the doctrine of predestination differs when it is presented in a sermon to the congregation? Calvin's theme in the sermon reads: 'Predestination precedes faith'. This formulation puts the emphasis on human faith. He addresses an issue which is of interest to the congregation in a very practical way. The electoral decree recedes into the background, especially because it is hidden to us. Calvin presupposes this decree, but he does not discuss it. The phrase 'before the foundation of the world' (Eph 1,4) is mentioned, but it is not dealt with more closely. In the Institutes, on the other hand, the decretum aeternum is repeatedly addressed.

* In the sermon, Calvin draws a conclusion from the insight that God's electoral decree is hidden to man. He puts emphasis on the distance between God and man. He does this to safeguard God's freedom to elect some, but also to leave some in their state of condemnation. Using impressive images, he describes God as the judge (whom it would be nonsensical to accuse), (objections 1 and 7); God's majesty, which crushes man, should man rebel against him (objections 1 and 4); God as creator who does not need to account to his creatures (objection 5); the superiority of Jesus' divine nature to his human nature (objection 5). The modest as well as the ungodly critics are accused of hypocrisy, pride, audacity, of being in the grip of Satan or even in his possession, people who are entirely lacking in any humility. 
* Yet, in contrast to the Intitutes, rejection is not presented in a dogmatic manner. Calvin restricts himself in his sermon to the statement that God passes over some when dispensing grace. Since all men have lapsed into sin, God is not unjust to the reprobate. P Jacobs had already shown that Calvin dealt with rejection differently in the Institutes and in his sermons. He concluded that the decretum horrible '.. as a developed theological idea cannot be found in the preaching of Cal$\operatorname{vin}^{\prime 16}$. The statement in the summary that we would actually be the reprobate, had we not received the grace of God, leaves the dogmatic system behind and addresses us only in a pastoral manner.

* The fact that a doctrine of reprobation has been relegated to the background in the sermon, results in predestination being explained in a christological manner. God's electoral decree and his act in Jesus Christ for our salvation are bound together. In the exposition of the most important Bible passages, the purpose of God is repeatedly depicted as salvation and redemption. The decree of God before the foundation of the world, which resulted in either election or rejection, is touched on, but later it is explained more fully as meaning grace for us in Jesus Christ. Rejection means exclusion from grace. In the Institutes, on the other hand, the connection with Christ is weak. It is true that in Institutes III, 24, 5, Christ is called 'the mirror of the election', and this image is impressively explained there, but this is an isolated passage. In the Institutes, God and his actions are brought to the fore, not his grace in Christ.

* As proof of the christological and soteriological interpretation of predestination, Calvin's exegesis of the Scriptures should be summarized. Calvin opposed objection 2 (it suffices to preach about repentance and faith only) with the answer that the whole Word of God should be preached.

- Romans 8, 28-30 is not concerned with God's foreknowledge of those 'who love God', but with the 'foreknowledge of God [which] carries with it the redemption' (from the wrath of God), because according to Acts 2, 23, Christ was crucified 'in accordance with the foreknowledge of God'. In the Institutes an explanation of Romans 8, 28-30 is lacking. True, in Institution III, 22, 6 Acts 2:23 is quoted, but the soteriological interpretation of the foreknowledge of God is lacking. 
- In Ephesians 1, 4 the decree of God means 'he does something good to us'. The sentence 'elected in Christ' means that we of ourselves are unworthy, but that God accepts us in his 'beloved Son' (Eph 1,6). The Institutes lacks this soteriological interpretation of 'in Christ'. There, the exegesis emphasizes the words 'according to the good pleasure of his will', which means it emphasizes the independence and the superiority of the decree of God.

- John 6, 44f, 10, 28 and similar passages in the sermon describe the road of salvation from eternal election to the certainty of election in Christ and further to the hearing of the gospel, and finally to faith. In the Institutes these passages are bound together in the same way, although the road to salvation is not as concretely recognizable.

- Romans 9, 6-20: Although the sermon begins in a strongly christological manner, the interpretation - as in the Institutes - turns to the independence of God's eternal decree. The summary in the sermon, however, is pastoral: 'God had elected us by means of his goodness'. Since Paul does not mention faith in Romans 9, as Calvin correctly remarks, Calvin does not find any occasion to address the congregation on the matter of faith in a pastoral way.

* Calvin leads the congregation away from the incomprehensibility of the election of God by means of the eschatological prospect which is also contained in the biblical testimony. At the 2nd objection his reply reads: 'On the last day we shall know why Jacob had been elected, but Esau rejected'. Also at the 9th objection Calvin points to the day of God's judgment, when it will be seen that God acts justly against the reprobate. Then we shall see God 'from face to face' (1 Cor 13, 12). At the 1st objection against Bolsec's thesis, that faith decides over election, Calvin objects by saying that faith is not distinguishable with certainty; God will only reveal it on the last day. At the moment it is impossible to say for certain who believes and who does not.

The eschatological aspect is lacking in the Institutes. There God's decision on salvation and on condemnation is hidden in his eternal decree (Inst III, 22, 4), but it is hidden to the congregation until the last judgment. Calvin's argument in the Institutes is determined by the categories cause and effect, author and receiver, origin and result - as is also the case with his opponent Pighius. In the sermon, on the other hand, he refers the congregation to the solution of every riddle on the last day. 
* The 9th objection asked for clear signs of God's election. Calvin mentions the 'feeling of the heart' or the movement of the conscience as proof. Since one's own works cannot endure before God, the knowledge of sin becomes 'proof of the conscience' that God's election is undeserved. With that, Calvin finds himself on the terrain of the experience of faith and uses it as proof. In this manner he was able to address the congregation in the sermon in a spiritual way. In the Institutes he avoids this argument.

* Calvin uses many images in the sermon. He endeavours to explain the majesty of God to the congregation, rather than to refer to the remote and hidden God. In the 2nd objection he asks the congregation: Imagine if God were to be brought before the judge and asked: Why did you do that? And God would have to answer! It is impossible for man to question God in such a way. The example does not only make it impossible further to question the justice of God, but Calvin also holds the question in itself to be dangerous to the questioner. The question casts the questioner into an abyss; this statement is repeated in the 8th objection. In the 5th objection he uses the image of the arrow shot from the cross-bow directly at heaven. The arrow will crush the marksman who is the questioner. Not only the impossibility of the accusation against God is shown by the image, but also - as in the image of the abyss - the danger to the person who rebels against God.

At the same time, Calvin wants to explain the problem of comprehension by means of these images: it is impossible to view God from a distance, but man meets him, the sinner encounters the Holy. The majesty of God is existentially menacing to man.

On the other hand, the image of the sun and its light, for the relation between election and conduct (objection 3 ), is truly abstract.

* The sermon on predestination and faith is, with respect to its train of thought, not always conclusive, as Calvin's answer to the 7th objection shows. But it makes use of the situation of being preached to, in which the congregation is addressed. For Calvin this is for all purposes a believing congregation. The we-style leads to being touched spiritually, as with the 'testimony of the conscience'. The constant reference to our dependence on God-given faith in election leads to concrete pastoral concern.

* A final conclusion: the Institutes should not be overvalued. (1) Its deficiency consists in the lack of a christological foundation for the predestination of God. The 
sermon notes this shortcoming, which has often been remarked upon, and shows how a serious error from the New Testament point of view may be eliminated. (2) In the same way the Institutes lacks the eschatological view of the doctrine of predestination. (3) As the sermon shows, rejection can also be spoken about in a manner which shows that you have been touched personally. (4) One should not speak about the majesty of God in an abstract manner. It can be vividly illustrated by means of images and expressed by the way in which one shows that one has been personally touched.

\section{End Notes}

1 R M Kingdon, Popular Reactions to the Debate between Bolsec and Calvin, in: W van't Spijker (Ed), Calvin. Erbe und Auftrag, Festschrift fur Wilhelm $H$ Neuser zu seinem 65. Geburtstag, Kampen 1991, 138ff.

2 The Register of the Company of Pastors of Geneva in the Time of Calvin, ed. and tr by Ph E Hughes, Grand Rapids 1966, 186. The French text CO 8, XIX.

3 P. Jacobs, Prädestination und Verantwortlichkeit bei Calvin, Neukirchen 1937, also takes Calvin's statements in his sermons into consideration.

4 Only three sermons of Calvin which he delivered in the Congrégation are known printed in the lifetime of Calvin, one of which is an exposition of his catechism. The sermon on John 1, 1-5 appears in CO 47, 461-484. The two sermons on Galatians 2 are not in the Corpus Reformatorum, but are published by R Peter, Deux congrégations et expositions du catéchisme, Paris 1964 (DRHPhR 38). See R. Peter (+), J. -Fr. Gilmont, Bibliotheca Calviniana. Les oeuvres de Jean Calvin publiées au XVle siecle, vol. 2, Genève 1994, 63/10; W de Greef, Johannes Calvijn zijn werk en schriften, Kampen 1989, 108v, 110v. Five more sermons exist in manuscript (Ex 1, 1-8; Jos 1, 1-5, 1, 6-11, 11; Is 1, 1-4); the sermons on Joshua were published by D Fischer, FZPhTh 34 (1987), 205-229, 35 (1988), 201-221, 38 (1991), 351-367. See W de Greef, Calvijn, 111 .

5 CO 58, 17-198. See R. Peter (+), J -Fr Gilmont, Bibliotheca Calviniana, Vol 2, 60/12; in 1562 they were again published as Trèze sermons traitans de l'election gratuite de Dieu en Jacob et de la rejection en Esau, 62/25. W de Greef, Calvijn, 105.

6 CO 51, 259-310. See R Peter (+), J -Fr Gilmont, Bibliotheca Calviniana, Vol 2, 62/6; W de Greef, Calvijn, $109 \mathrm{f}$

7 CO 8, 85-140. R Peter (+), J -Fr Gilmont, Bibliotheca Calviniana, Vol 2, 62/19; W de Greef, Calvijn, $109 f$.

8 On average Calvin's sermons cover 12-14 columns in the CO; this one, however, extends over 24 columns. 
9 The Bolsec Controversy on Predestination from 1551 to 1553. Translation of selected Letters and other Documents, Grand Rapids 1990, 131-151 (duplicated Ms). Also: The Bolsec Controversy on Predestination from 1551 to 1555, Vol 1, Lewiston 1993, 695-720.

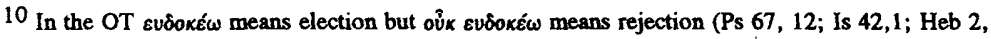

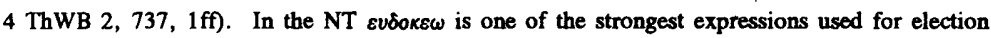
(ThWB 2, 739, 26f). The concept renders the decree of God (ThWB 2, 739.11f). In Ephesians

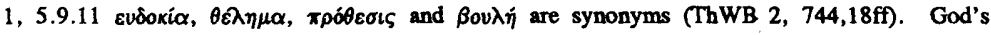
choice $(\operatorname{Rm} 9,18)$ and the pleasure of his will $(E p h ~ 1,5)$ thus concur - a fact that is important for Calvin's exegesis. In the passage in Ephesians, God's kind disposition comes to the fore (ThWB 2, 743, 48ff, 745, 5ff).

11 Calvin uses it without the impressive application in Institutio III, 21, 5.

12 Text according to J T McNeill - F L Battles, Calvin: Institutes of the Christian Religion, Philadelphia 1960, vol 2, 933 = OS IV, 380,9-13.

13 McNeill-Battles, 2,933 = OS IV 380, 15-21.

14 McNeill-Battles, 2,933 = OS IV, 380, 21-23.

15 See W H Neuser, Dogma und Bekenntnis in der Reformation: Von Zwingli und Calvin bis zur Synode von Westminster, in: C Andresen, Handbuch der Dogmen- und Theologiegeschichte, Bd 2, Goettingen 1980, 380.

16 Prädestination und Verantwortlichkeit bei Calvin, Neukirchen 1937, $158 f$. 